Public report

\title{
Dynamics of urological morbidity of the Central Federal District population (Russian Federation) in 2013-2017
}

\author{
Aimar A. Orudzhev ${ }^{1}$, Aleksey V. Breusov ${ }^{1,2}$ \\ ${ }^{1}$ Peoples' Friendship University of Russia, Moscow, Russia \\ ${ }^{2}$ Kursk State Medical University, Kursk, Russia
}

Received 25 September 2019, Revised 4 February 2020, Accepted 18 February 2020

(C) 2019, Orudzhev A.A., Breusov A.V.

(C) 2019, Russian Open Medical Journal

Abstract: Based on official statistics of the Russian Federal State Statistics Service and the Ministry of Healthcare, the article analyzes the state and dynamics of urological morbidity, along with urologic cancer incidence and mortality in adult population of the Central Federal District vs. entire Russian Federation (RF). It was established that genitourinary diseases are consistently at the top in the structure of RF population morbidity and mortality, often being among leading causes of disabilities as well. The analysis results, using the case-studies of specific nosological forms, constitute an important methodological and informative base for strategic planning of developing both medical and preventive care in the patients, as well as create essential basis for further improvement of specialized outpatient and inpatient types of a health care.

Keywords: urological morbidity, urologic cancer incidence, morbidity trends, mortality from urologic diseases, improving urological care.

Cite as Orudzhev AA, Breusov AV. Dynamics of urological morbidity of the Central Federal District population (Russian Federation) in 2013-2017. Russian Open Medical Journal 2020; 9: e0108.

Correspondence to Aleksey Breusov. Address: Miklukho-Maklaya, 10, build. 2, Moscow, 117198, Russia. Tel.: +79035116080. Email: ab69@yandex.ru.

\section{Introduction}

Genitourinary system (GS) diseases are among priority issues of contemporary medicine. As noted by many authors and confirmed by official statistics, there was a significant morbidity increase in this class of diseases over the past decade [1-4]. By the end of the twentieth century, the proportion of GS diseases in the structure of the total morbidity incidence was $4-5 \%$. Currently, according to the statistics, this number in Russian Federation (RF) increased up to 7\%, or still more in some RF regions and foreign countries [2, 4-6].

In 2017, the GS diseases' share in the general morbidity structure of RF population surpassed the above-mentioned cut-off value and reached $7.17 \%(161,776.0$ and $11,594.3$ cases per 100 thousand people, respectively), while the annual growth rate was $0.08 \%$. The highest growth rates were observed for the following nosologies: diseases of prostate and bladder, urolithiasis, and male infertility $[1,3,6]$. Similar to those nosological forms, there was even more pronounced increase in urologic oncology - especially stage I or II tumors with localization of malignant neoplasms (MN) in the kidneys and prostate, which led to augmented disability and mortality rates, predominantly, in the working age population [710].

Analysis of urological morbidity dynamics is an important methodological and informational basis for strategic planning of specialized medical care development. It creates required prerequisites for designing a set of measures for developing residential outpatient and inpatient care. Hence, the objective of our research stated below.
Study objective involved analyzing uronephrological morbidity (including urologic cancer incidence) in adult population of the Central Federal District (CFD) over 2013-2017 in comparison with similar data for entire Russian Federation (RF) in order to evaluate morbidity levels and dynamics.

\section{Material and Methods}

\section{Data source}

Data sources for the study included official statistics, reporting forms of municipalities - such as form No. 12 "Information on the number of diseases registered in patients living in the service area of a medical institution (MI)", form No. 30 "Ml annual medical report", scientific (magazines and information portals) and methodological literature.

\section{Study design}

The research design consisted of three consecutive stages: Stage 1 - analysis of literature sources, official statistics on the topic under study, development of the research program and the formulation of its objective; Stage 2 - copying data from their official sources and their statistical processing; Stage 3 - data analysis, synthesis and discussion of the results. The dynamics of morbidity indicators over 2013-2017 was analyzed for entire RF vs. entire CFD vs. particular CFD subjects, using absolute growth and growth rate indices, along with building a forecast trend graph. 


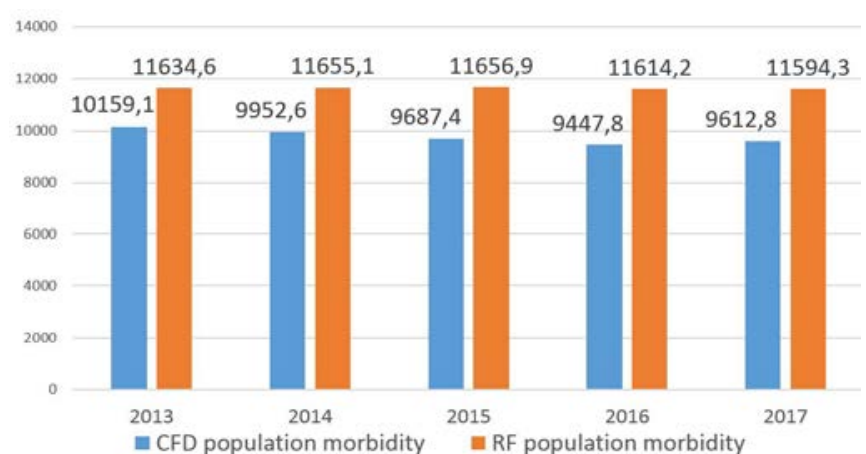

Figure 1. Comparative dynamics of the overall GS diseases morbidity of the Central Federal District population vs. entire Russian Federation population over 2013-2017 (per 100,000 residents).

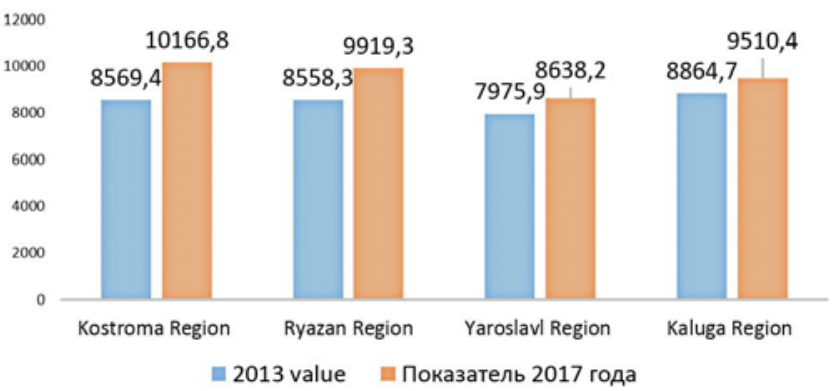

Figure 2. Central Federal District regions with highest growth rates of GS diseases morbidity over 2013-2017 (per 100,000 residents).

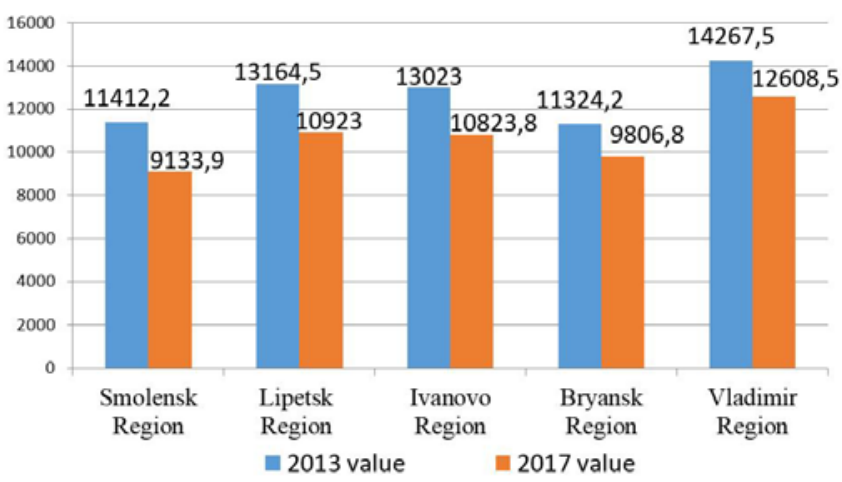

Figure 3. Central Federal District regions with the highest rate of decline in the overall incidence of GS diseases (per 100,000 residents).

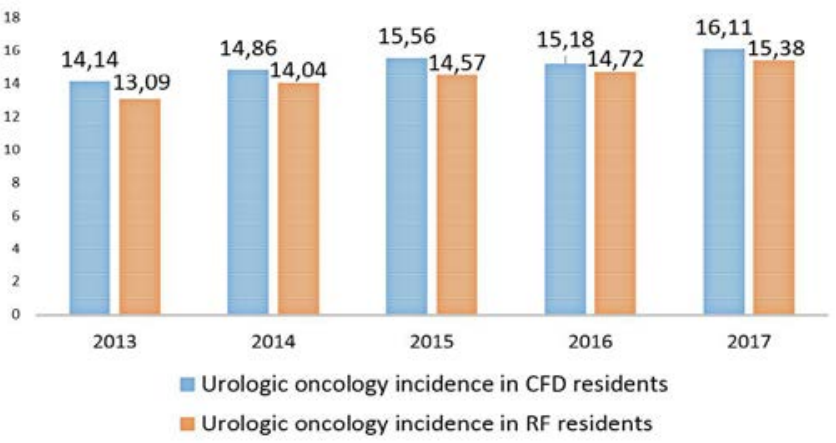

Figure 4. Dynamics of urologic oncology incidence in the population of the Central Federal District and entire Russian Federation over 2013-2017 (per 100,000 residents).

\section{Statistical analysis}

Analyzing our results involved calculating relative indicators and assessing statistical significance of the differences in population means (Student's t-test). Computed t-criterion values were compared with tabular values, while the differences in the indicators were considered statistically significant at significance level of $p<0.05$. The confidence intervals for the means were calculated at a confidence level of at least 0.95 [11]. Statistical data processing was performed using the PASW (Predictive Analytics SoftWare) Statistics 22 software.

\section{Results}

\section{Incidence of GS diseases in the population}

The total registered incidence of GS diseases in RF in 2017 was $17,025,367$ (absolute number), or $11,594.3$ (per 100,000 of the population), which was lower than in 2013 (absolute number of $16,821,274$ people, or $11,634.6$ per 100 thousand residents). The growth rate of this indicator (per 100,000 population) amounted to $-0.4 \%$ over the specified period of time. The incidence rate of GS diseases in CFD population had lower values: 10,159.1 in 2013 and 9612.8 in 2017 (per 100 thousand people). However, the growth rate of this indicator in CFD significantly exceeded its values for the entire RF and amounted to $-5.4 \%$ over the analyzed period of time (Appendix 1, Figure 1).

Considering particular CFD subjects, four of those had the highest growth rate of GS diseases per 100,000 residents: Kostroma Region $(+18.6 \%)$, Ryazan Region $(+15.9 \%)$, Yaroslavl Region $(+8.3 \%)$ and Kaluga Region $(+7.3 \%)(p<0.05)$ (Appendix 1, Figure 2).

Over the analyzed period of time, the highest rate of decline in this indicator (per 100 thousand people) was recorded in the following CFD subjects: Smolensk Region (-20.0\%), Lipetsk Region (-17.1\%), Ivanovo Region (-16.9\%), Bryansk Region (-13.4\%), Vladimir Region $(-11.6 \%)$ (differences were significant, $p<0.05$ ) (Appendix 1, Figure 3).

\section{Urologic cancer incidence}

Urologic oncology, as well as overall morbidity related to malignant neoplasms of various localizations, demonstrated a distinct upward trend in all CFD regions, as well as in the entire RF. For the period from 2013-2017, the growth rate of this pathology was $13.93 \%$ in the CFD vs. $17.49 \%$ in the RF (per 100,000 residents), the annual growth rate was $2.8 \%$ vs. $3.5 \%$, respectively (Appendix 2, Figure 4).

Mortality from GS MN in RF for the period of time from 20132017 increased by $6.7 \%$, vs. $5.7 \%$ in CFD. Detailed data on residential mortality from $\mathrm{MN}$ in general, and $\mathrm{MN}$ of GS, for both entire RF and CFD are given in Table 1.

The proportion of deaths from GS MN in the structure of mortality from all malignant neoplasms annually was over $17 \%$. In the entire RF, the proportion of the patients, who died during their first year after the $\mathrm{MN}$ diagnosis and registration in the previous year, declined from $25.3 \%$ in 2013 to $22.5 \%$ in 2017. Residential mortality rates from major nosological categories of GS MN are compiled in Table 2. The following diagnoses sensu ICD-10 are assigned to $\mathrm{MN}$ of other GS organs: $\mathrm{C65}$ (MN of the renal pelvis); C66 (MN of ureter) and C68 (MN of other and unspecified urinary organs). 
Table 1. Residential mortality in the Russian Federation and Central Federal District from malignant neoplasms over 2013-2017

\begin{tabular}{|c|c|c|c|c|c|c|c|c|c|c|}
\hline \multirow{3}{*}{ Indicators } & \multicolumn{10}{|c|}{ Years } \\
\hline & \multicolumn{4}{|c|}{2013} & \multicolumn{2}{|c|}{2015} & \multicolumn{2}{|c|}{2016} & \multicolumn{2}{|c|}{2017} \\
\hline & $\mathrm{RF}$ & CFD & $\mathrm{RF}$ & CFD & $\mathrm{RF}$ & CFD & $\mathrm{RF}$ & CFD & $\mathrm{RF}$ & CFD \\
\hline Total died from MN, absolute numbers & 288,636 & 85,320 & 286,900 & 84,311 & 296,476 & 83,973 & 295,729 & 84,487 & 290,662 & 81,256 \\
\hline Total died from MN, absolute numbers & 288,636 & 14,997 & $49,, 527$ & 14,679 & 50,281 & 14,699 & 51,371 & 14,894 & 50,813 & 14,408 \\
\hline GS MN, per 100,000 people & 32.7 & 33.3 & 34.3 & 33.7 & 34.5 & 33.3 & 34.0 & 34.5 & 34.9 & 35.2 \\
\hline Died from GS MN,\% & 16.3 & 17.6 & 17.3 & 17.4 & 17.0 & 17.5 & 17.4 & 17.6 & 17.5 & 17.7 \\
\hline Growth rate, $\%$ & - & - & 4.9 & 1.2 & 0.6 & -1.2 & -1.4 & 3.6 & 2.7 & 2.1 \\
\hline
\end{tabular}

Table 2. Comparative characteristics of genitourinary system malignant neoplasm-caused mortality rates

\begin{tabular}{|c|c|c|c|c|c|c|c|c|}
\hline \multirow[t]{3}{*}{ Subject } & \multicolumn{2}{|r|}{ Prostate } & \multicolumn{2}{|r|}{ Kidney } & \multicolumn{2}{|c|}{ Urinary bladder } & \multicolumn{2}{|c|}{ Other GS organs } \\
\hline & \multicolumn{8}{|c|}{ Malignant neoplasm localtion in 2013} \\
\hline & Abs. no. & $\begin{array}{c}\text { Rel. no. per } \\
100,000 \text { residents }\end{array}$ & Abs. no. & $\begin{array}{c}\text { Rel. no. per } \\
100,000 \text { residents }\end{array}$ & Abs. no. & $\begin{array}{c}\text { Rel. no. per } \\
100,000 \text { residents }\end{array}$ & Abs. no. & $\begin{array}{c}\text { Rel. no. per } \\
100,000 \text { residents }\end{array}$ \\
\hline RF & 11111 & 16.72 & 8459 & 5.89 & 6561 & 4.57 & 445 & 0.42 \\
\hline \multirow[t]{3}{*}{ CFD } & 3364 & 18.95 & 2409 & 6.22 & 1993 & 5.14 & 171 & 0.44 \\
\hline & \multicolumn{8}{|c|}{ Malignant neoplasm location in 2017} \\
\hline & Abs. no. & $\begin{array}{c}\text { Rel. no. per } \\
100,000 \text { residents }\end{array}$ & Abs. no. & $\begin{array}{c}\text { Rel. no. per } \\
100,000 \text { residents }\end{array}$ & Abs. no. & $\begin{array}{c}\text { Rel. no. per } \\
100,000 \text { residents }\end{array}$ & Abs. no. & $\begin{array}{c}\text { Rel. no. per } \\
100,000 \text { residents }\end{array}$ \\
\hline RF & 12565 & 18.46 & 8386 & 5.71 & 6094 & 4.15 & 558 & 0.40 \\
\hline CFD & 3607 & 20.01 & 2271 & 5.78 & 1744 & 4.44 & 131 & 0.33 \\
\hline \multicolumn{9}{|c|}{ Growth rate, absolute and relative, per 100,000 residents } \\
\hline & Abs. no. & Rel. no. & Abs. no. & Rel. no. & Abs. no. & Rel. no. & Abs. no. & Rel. no. \\
\hline RF & 1454 & $10.4^{*}$ & -73 & -3.1 & -467 & $-9.2^{*}$ & 113 & -4.8 \\
\hline CFD & 243 & 5.6 & -138 & -7.1 & -249 & $-13.4^{*}$ & -40 & -25.0 \\
\hline
\end{tabular}

* differences are significant at $\mathrm{p}<0.05$; Abs. no. - absolute numbers; Rel. no. - relative numbers.

Data in Table 2 imply that, over the analyzed period, solely mortality from prostate cancer had a steady upward trend: $+10.4 \%$ (RF) vs. $+5.6 \%$ (CFD). As for MN of other locations (kidney, urinary bladder, and other GS organs), there was a tendency to decrease in these indicators.

\section{Discussion}

Our study confirmed high significance of conducting a systematic analysis of the dynamics related to urological morbidity and urologic cancer incidence of the population, along with monitoring the mortality caused by GS MN. Such analysis could serve a methodological basis for implementing strategic planning methods aimed at specialized medical care.

When analyzing statistical resources on residential morbidity incidence in the RF vs. CFD subjects, we obtained the following data. The absolute number of registered adult patients diagnosed with GS vs. relative index (per 100,000 residents) in the Russian Federation in 2013 was $16,821,274.0$ vs. 11,634.6. In 2017, this indicator decreased by $0.4 \%$ and amounted to $17,025,367$ vs. $11,594.3$, respectively.

A comparative analysis of the relative incidence of GS diseases in CFD regions vs. entire RF (per 100 thousand residents) showed declining trends for both CFD and RF. However, in a number of CFD subjects, during 2013-2017, there has been a steady upward trend, confirmed by the studies of domestic and foreign scientists [2-4]. Moreover, the dynamics of declining morbidity rate in this nosological category was developing unevenly over five years. In RF, between 2013-2015, its decline was obvious due to improvements in diagnosing and detecting GS diseases in the primary health care sector; while since 2016 , there has been a slight drawback, which, apparently, can be explained by a higher detection rate of this pathology. As for CFD, a different picture was observed: from 2013-2016, there was a significant GS morbidity decline, which can be explained by successful implementation of comprehensive preventive programs, additional medical examinations, and implementation of a three-level system of provisioning medical care to the population $[7,9]$.

The increased attention to the problems of oncological morbidity is due to a steady tendency towards an increase in its incidence rate worldwide. The latter is projected to continually increase in virtually all countries in the years to come, which could be explained by a number of objective and subjective reasons, including population aging, along with environmental, economic and other factors $[3,4,9,10,12]$. During the analyzed period, the indicators of active detection of the patients with GS MN at the early stages significantly improved for both entire Russian Federation and CFD. This progress was caused by multiple factors, such as changing demographic situation (a steady increase in the elderly people share in the general structure of the country population); ongoing organizational changes in the healthcare sector of the RF (increased coverage of medical examinations of the residents belonging to the various age groups); expansion of oncological institutions' network; and emergence of new and improvement of existing diagnostic methods.

As for specialized medical institutions, there were 96 oncological dispensaries in the RF in 2017, 92 of those had hospitals, and 2 had specialized oncological hospitals. The greatest number of the patients with tumors of various localizations is detected at the early stages (I-II), which may also indicate an increase in the vigilance of the doctors of various specialties, especially in the primary care units. The analysis of the incidence structure in malignant neoplastic diseases by nosological categories showed that the leading localizations in the general 
structure of residential GS oncological morbidity were prostate, uterine corpus, kidney, urinary bladder, and ovary $[6,9,10]$.

The analysis of mortality from GS MN revealed that this indicator had a steady upward trend both in the RF and all regions of the CFD, as well as in other countries [1, 4, 8-10, 12]. An average annual mortality growth rate was stably high and ranged from $0.42 \%$ (CFD) to $0.54 \%$ (entire RF), which corresponded to the data for most European countries. In the structure of mortality for this nosological class, the first three places are taken by prostate cancer ( $4.3 \%$ in the RF vs. $4.4 \%$ in CFD), kidney MN ( $2.9 \%$ in the RF vs. $2.8 \%$ in CFD), and MN of ovaries ( $2.6 \%$ in RF vs. $2.8 \%$ in CFD).

An analysis of the mortality trends in RF population from GS cancer, with calculation of its forecast levels, showed that in 2020, the mortality rate in entire RF would increase up to $35.5 \pm 1.2$ cases per 100 thousand residents vs. $36.1 \pm 1.3$ in CFD.

\section{Conclusion}

Thus, the data obtained from our study, convincingly confirmed that residential GS morbidity, prevalence of GS MN and mortality rate from those are high and tend to increase. The noted trends are associated with increase in coverage of various residential age groups by clinical examination, implementation of a three-level system of provisioning residential medical care, improvement in the detection of GS MN, especially at early stages, via new effective diagnostic methods and expansion of the oncological institutions' network. It should be also noted that domestic urological care still has a number of shortcomings, such as lack of continuity in the work among the clinic and the hospital, insufficient staffing by primary health care specialists, insufficient effectiveness of disease prevention system, poor quality and low efficiency of medical diagnostic and rehabilitation measures and health education of the population.

\section{Ethical Issues}

The article does not contain studies involving humans or animals performed by any of the authors.

\section{Conflict of Interest}

No conflict of interest is stated.

\section{References}

1. Morbidity of the whole population of Russia in 2018. Statistical materials. Moscow, 2019; 140 p. Russian. https://www.rosminzdrav.ru/ministry/61/22/stranitsa-

979/statisticheskie-i-informatsionnye-materialy/statisticheskiematerialy

2. Apolikhin OI, Sivkov AV, Solntseva TV. Disability as a Result of Urinary System Diseases in Russian Federation according to Official Statistics. Experimental and Clinical Urology 2012; (1): 4-11. Russian. https://www.elibrary.ru/item.asp?id=17775512\&.

3. Glybochko PV, Alyaev YuG. Russian Urology in the XXI Century. Urologiia 2015; (5): 4-9. Russian. https://www.elibrary.ru/item.asp?id=24881900.

4. McAninch JW, Lue TF. Smith and Tanagho's general urology. 18th Ed. San Francisco, USA: McGraw-Hill Medical, 2012; 768 p. https://accesssurgery.mhmedical.com/book.aspx?bookID=508.

5. Prostate diseases. Yu.G. Alyaev, ed. Moscow, Russia: Geotar-Media, 2009; 240 p. Russian. https://www.rosmedlib.ru/book/ISBN9785970408704.html.

6. The demographic yearbook of Russia. 2017: Statistical handbook. G.K. Oksenojt, S.Yu. Nikitina, eds. Moscow, Russia: Rosstat, 2017; 263 p.
Russian.

http://old.gks.ru/wps/wcm/connect/rosstat main/rosstat/ru/statistics Lpublications/catalog/doc 1137674209312.

7. Krivonos OV, Skachkova El, Malkhasyan VA, Pushkar DYu. Current state, challenges and prospects for the development of the Russian urological service. Urologiia 2012; (5): 5-12. Russian. https://www.elibrary.ru/item.asp?id=18193388.

8. Maksimov VA, Pushkar DYu, Umarov MS. A modern look at prostate cancer screening. Urologiia 2009; (5): 74-77. Russian. https://www.elibrary.ru/item.asp?id=13074791.

9. Malignant neoplasms in Russia in 2013 - 2017 (morbidity and mortality) A.D. Kaprin, V.V. Starinsky, G.V. Petrova, eds. Moscow, Russia: MNIOI n.a. PA Herzen, 2018; 250 p. Russian. http://www.oncology.ru/service/statistics/malignant tumors/2018.pdf.

10. Urological oncology. V.H. Nargund, D. Raghavan, H.M. Sandler, eds. London: Springer, 2015; 907 p. http://doi.org/10.1007/978-0-85729482-1.

11. Public Health and Healthcare: a textbook for medical students. 6th ed. V.A. Minyaev, N.I. Vishnyakov, eds. Moscow, Russia: MEDpress-inform, 2012; 655 p. Russian. https://elibrary.ru/item.asp?id=19562722.

12. Wang SC, Sung WW, Kao YL, Hsieh TY, Chen WJ, Chen SL, et al. The gender difference and mortality-to-incidence ratio relate to health care disparities in bladder cancer: National estimates from 33 countries. Sci Rep 2017; 7(1): 4360. https://doi.org/10.1038/s41598 017-04083-z.

Authors:

Aimar A. Orudzhev - MD, PhD student, Department of Public Health, Healthcare and Hygiene, Institute of Medicine, Peoples' Friendship University of Russia, Moscow, Russia. https://orcid.org/0000-0002-0518$\underline{5521 .}$.

Aleksey V. Breusov - MD, DSc, Professor, Department of Public Health, Healthcare and Hygiene, Institute of Medicine, Peoples' Friendship University of Russia, Moscow, Russia; Head of the Department of Public Health and Healthcare, Faculty of Postgraduate Education with a Training Center for Lean Technologies, Kursk State Medical University, Kursk, Russia. http://orcid.org/0000-0003-2335-3338. 
Appendix 1. Population morbidity based on genitourinary system diseases in the RF and Central Federal District territories

\begin{tabular}{|c|c|c|c|c|c|c|c|c|c|c|c|}
\hline \multirow[b]{2}{*}{$\begin{array}{l}\text { Federal subjects of } \\
\text { Russia }\end{array}$} & \multicolumn{2}{|c|}{2013} & \multicolumn{2}{|c|}{2014} & \multicolumn{2}{|c|}{2015} & \multicolumn{2}{|c|}{2016} & \multicolumn{2}{|c|}{2017} & Growth rate* \\
\hline & Absolute & $\begin{array}{l}\text { Relative } \\
\text { (per } 100 \\
\text { thousand } \\
\text { residents) }\end{array}$ & Absolute & $\begin{array}{l}\text { Relative } \\
\text { (per } 100 \\
\text { thousand } \\
\text { residents) }\end{array}$ & Absolute & $\begin{array}{l}\text { Relative } \\
\text { (per } 100 \\
\text { thousand } \\
\text { residents) }\end{array}$ & Absolute & $\begin{array}{l}\text { Relative } \\
\text { (per } 100 \\
\text { thousand } \\
\text { residents) }\end{array}$ & Absolute & $\begin{array}{l}\text { Relative } \\
\text { (per } 100 \\
\text { thousand } \\
\text { residents) }\end{array}$ & $\begin{array}{c}\text { Per } 100 \\
\text { thousand } \\
\text { residents. } 2017 \\
\text { to } 2013 . \%\end{array}$ \\
\hline RUSSIA & $16,821,274$ & $11,634.6$ & $17,047,406$ & $11,655.1$ & $17,050,217$ & $11,656.9$ & $17,019,933$ & $11,614.2$ & $17,025,367$ & $11,594.3$ & -0.4 \\
\hline $\begin{array}{l}\text { CENTRAL FEDERAL } \\
\text { DISTRICT }\end{array}$ & $3,929,448$ & $10,159.1$ & 3876703 & $9,952.6$ & $3,773,378$ & $9,687.4$ & $3,694,486$ & $9,447.8$ & $3,774,020$ & $9,612.8$ & -5.4 \\
\hline Belgorod Region & 185,274 & $12,023.1$ & 176,400 & $11,395.8$ & 177,314 & $11,454.9$ & 183,868 & $11,861.4$ & 169,446 & $10,922.3$ & -9.2 \\
\hline Bryansk Region & 141,968 & $11,324.2$ & 137,251 & $11,132.0$ & 128,193 & $10,397.3$ & 120,995 & $9,871.2$ & 119,227 & $9,806.8$ & -13.4 \\
\hline Vladimir Region & 202,847 & $14,267.5$ & 188,281 & $13,394.9$ & 183,590 & $13,061.2$ & 183,411 & $13,127.3$ & 174,498 & $12,608.5$ & -11.6 \\
\hline Voronezh Region & 242,458 & $10,404.2$ & 249,427 & $10,699.8$ & 255,644 & $10,966.4$ & 272,750 & $11,688.6$ & 248,426 & $10,641.1$ & +2.3 \\
\hline Ivanovo Region & 136,606 & $13,023.0$ & 121,760 & $11,742.6$ & 107,352 & $10,353.1$ & 27,726 & $2,692.3$ & 110,285 & $10,823.8$ & -16.9 \\
\hline Kaluga Region & 89,142 & $8,864.7$ & 91,767 & $9,081.5$ & 97,335 & $9,632.5$ & 104,809 & $10,379.5$ & 96,375 & $9,510.4$ & +7.3 \\
\hline Kostroma Region & 56,464 & $8,569.4$ & 60,464 & $9,239.8$ & 58,609 & $8,956.3$ & 51,785 & $7,949.2$ & 65,651 & $10,166.8$ & +18.6 \\
\hline Kursk Region & 90,141 & $8,053.6$ & 84,945 & $7,602.2$ & 81,991 & $7,337.8$ & 84,566 & $7,550.4$ & 83,174 & $7,432.5$ & -7.7 \\
\hline Lipetsk Region & 153,003 & $13,164.5$ & 142,200 & $12,281.2$ & 127,106 & $10,977.6$ & 125,858 & $10,886.5$ & 125,965 & $10,923.0$ & -17.1 \\
\hline Moscow Region & 557,365 & $7,908.0$ & 580,358 & $8,025.9$ & 578,427 & 7,999.2 & 569,937 & $7,787.5$ & 570,166 & $7,639.5$ & -3.4 \\
\hline Orel Region & 111,269 & $14,342.0$ & 107,871 & $14,096.5$ & 102,111 & $13,343.8$ & 106,307 & $13,992.9$ & 107,970 & $14,376.2$ & +0.2 \\
\hline Ryazan Region & 97,963 & $8,558.3$ & 101,172 & $8,910.4$ & 114,054 & $10,044.9$ & 107,151 & $9,481.5$ & 111,503 & 9,919.3 & +15.9 \\
\hline Smolensk Region & 111,290 & $11,412.2$ & 92,685 & $9,606.7$ & 92,267 & $9,563.4$ & 85,865 & $8,957.1$ & 86,888 & $9,133.9$ & -20.0 \\
\hline Tambov Region & 109,798 & $10,206.7$ & 112,309 & $10,571.0$ & 103,818 & $9,771.8$ & 103,012 & $9,807.9$ & 99,770 & $9,621.6$ & -5.7 \\
\hline Tver Region & 124,508 & $9,333.0$ & 124,213 & $9,445.3$ & 122,040 & $9,280.1$ & 123,348 & $9,453.8$ & 125,771 & $9,747.2$ & +4.4 \\
\hline Tula Region & 175,390 & $11,445.2$ & 173,311 & $11,450.5$ & 171,693 & $11,343.6$ & 163,075 & $10,825.1$ & 166,018 & $11,100.2$ & -3.1 \\
\hline Yaroslavl Region & 101,427 & 7,975.9 & 95,623 & 7,519.7 & 99,330 & 7,811.2 & 102,556 & $8,063.1$ & 109,550 & $8,638.2$ & +8.3 \\
\hline Moscow & $1,242,535$ & $10,372.2$ & $1,236,666$ & $10,138.6$ & $1,172,504$ & $9,612.6$ & $1,177,467$ & $9,549.5$ & $1,203,337$ & $9,670.4$ & -6.8 \\
\hline
\end{tabular}

* Growth rate is over 5 yr time span is given in relative extensive indicators (\%) per 100 thousand residents.

Appendix 2. Population morbidity based on urological cancer incidence in the RF and Central Federal District territories

\begin{tabular}{|c|c|c|c|c|c|c|c|c|c|c|c|}
\hline \multirow[b]{2}{*}{$\begin{array}{l}\text { Federal subjects of } \\
\text { Russia }\end{array}$} & \multicolumn{2}{|c|}{2013} & \multicolumn{2}{|c|}{2014} & \multicolumn{2}{|c|}{2015} & \multicolumn{2}{|c|}{2016} & \multicolumn{2}{|c|}{2017} & \multirow{2}{*}{$\begin{array}{l}\text { Growth rate* } \\
\text { Per } 100 \\
\text { thousand } \\
\text { residents. } 2017 \\
\text { to } 2013 . \%\end{array}$} \\
\hline & Absolute & $\begin{array}{c}\text { Relative } \\
\text { (per } 100 \\
\text { thousand } \\
\text { residents) }\end{array}$ & Absolute & $\begin{array}{l}\text { Relative } \\
\text { (per } 100 \\
\text { thousand } \\
\text { residents) }\end{array}$ & Absolute & $\begin{array}{l}\text { Relative } \\
\text { (per } 100 \\
\text { thousand } \\
\text { residents) }\end{array}$ & Absolute & $\begin{array}{l}\text { Relative } \\
\text { (per } 100 \\
\text { thousand } \\
\text { residents) }\end{array}$ & Absolute & $\begin{array}{l}\text { Relative } \\
\text { (per } 100 \\
\text { thousand } \\
\text { residents) }\end{array}$ & \\
\hline RUSSIA & 110,874 & 13.09 & 120,092 & 14.04 & 124,979 & 14.57 & 127,056 & 14.72 & 132,709 & 15.38 & 17.49 \\
\hline $\begin{array}{l}\text { CENTRAL FEDERAL } \\
\text { DISTRICT }\end{array}$ & 31,938 & 14.14 & 33,495 & 14.86 & 35,217 & 15.56 & 34,704 & 15.18 & 36,794 & 16.11 & 13.93 \\
\hline Belgorod Region & 1,243 & 13.52 & 1,340 & 14.53 & 1,410 & 15.18 & 1,432 & 14.72 & 1,456 & 15.58 & 15.24 \\
\hline Bryansk Region & 1,112 & 15.52 & 1,127 & 15.77 & 1,054 & 14.62 & 1,072 & 14.61 & 1,178 & 16.04 & 3.35 \\
\hline Vladimir Region & 1,042 & 12.56 & 1,275 & 15.42 & 1,367 & 16.66 & 1,351 & 16.32 & 1,330 & 16.48 & 31.21 \\
\hline Voronezh Region & 1,854 & 13.72 & 2,124 & 15.68 & 2,153 & 15.88 & 2,099 & 15.39 & 2,202 & 16.14 & 17.64 \\
\hline Ivanovo Region & 1,015 & 16.31 & 964 & 15.76 & 1,105 & 18.24 & 1,181 & 19.78 & 1,214 & 20.17 & 23.67 \\
\hline Kaluga Region & 1,112 & 14.12 & 1,227 & 15.89 & 1,259 & 16.59 & 1,306 & 16.93 & 1,303 & 17.28 & 22.38 \\
\hline Kostroma Region & 967 & 16.66 & 988 & 17.15 & 1,050 & 18.09 & 1,048 & 18.24 & 977 & 16.71 & 0.30 \\
\hline Kursk Region & 575 & 14.49 & 637 & 15.86 & 560 & 14.34 & 571 & 14.38 & 589 & 14.60 & 0.76 \\
\hline Lipetsk Region & 968 & 14.07 & 1,071 & 16.14 & 1,131 & 16.95 & 1,226 & 18.11 & 1,134 & 16.52 & 17.41 \\
\hline Moscow Region & 1,086 & 15.62 & 1,038 & 14.92 & 1,122 & 16.44 & 1,109 & 16.15 & 1,073 & 15.71 & 0.58 \\
\hline Orel Region & 5,404 & 13.00 & 5,863 & 14.15 & 6,180 & 14.64 & 5,838 & 13.59 & 6,232 & 14.37 & 10.54 \\
\hline Ryazan Region & 769 & 16.35 & 790 & 17.33 & 839 & 18.49 & 829 & 18.26 & 815 & 18.10 & 10.70 \\
\hline Smolensk Region & 1,095 & 16.25 & 1,149 & 17.12 & 1,273 & 19.26 & 1,147 & 17.17 & 1,175 & 17.78 & 9.42 \\
\hline Tambov Region & 748 & 12.82 & 848 & 14.74 & 810 & 14.02 & 805 & 14.16 & 856 & 15.10 & 17.79 \\
\hline Tver Region & 878 & 13.63 & 1,035 & 16.38 & 1,020 & 16.00 & 970 & 15.56 & 972 & 15.75 & 15.56 \\
\hline Tula Region & 1,421 & 15.64 & 1,543 & 17.33 & 1,580 & 17.81 & 1,507 & 16.83 & 1,637 & 18.75 & 19.89 \\
\hline Yaroslavl Region & 1,185 & 15.67 & 1,256 & 17.12 & 1,271 & 17.12 & 1,263 & 16.89 & 1,360 & 18.21 & 16.21 \\
\hline City of Moscow & 9,456 & 13.88 & 9,227 & 13.39 & 10,023 & 14.47 & 9,983 & 14.23 & 11,298 & 16.03 & 15.49 \\
\hline
\end{tabular}

* Growth rate is over 5 yr time span is given in relative extensive indicators (\%) per 100 thousand residents. 